\title{
Implementasi statistika sebagai alat analisis dalam pengambilan keputusan di bidang pendidikan
}

\author{
Jerhi Wahyu Fernanda ${ }^{1 *}$, Noer Hidayah² \\ ${ }^{1}$ Institut Agama Islam Negeri (IAIN) Kediri, Indonesia, email: fernanda.jerhi@iainkediri.ac.id \\ 2Institut Agama Islam Negeri (IAIN) Kediri, Indonesia, email: noer_hid@yahoo.com \\ *Koresponden penulis
}

\section{Info Artikel \\ Diajukan: 13 Feb 2021 \\ Diterima: 30 Jul 2021 \\ Diterbitkan: 16 Agst 2021 \\ Keywords: \\ statistics; normal \\ distribution; binomial \\ Kata Kunci: \\ statistika; distribusi normal; binomial}

Lisensi:

cc-by-sa

\begin{abstract}
Statistics is a part of mathematics lessons in senior high school XII classes as well as mathematics specialization class XII. A comprehensive understanding of the basic concepts of statistics is needed to convey the material in class. The results of the discussion with the Mathematics MGMP of Kediri City, a workshop is needed to deepen the understanding of mathematics teachers, especially in the material of normal distribution and binomial distribution. In addition, Material about item analysis and standard setting is need to be introduced. Both materials can be used in evaluating learning. The workshop was held in two days. The first workshop held on 4 November 2020. Material for this day was normal distribution. At the end of the activity on this date, participants were given practice questions that should to be uploaded on google classroom. Second workshop held on 17 November 2020. Participatn are given material about binomial distribution, item analysis, and standard setting. This workshop has increased the level of understanding of participants on the material of binomial distribution and normal distribution. The increase in understanding is measured by the evaluation of the answers to the practice questions collected by the participants and the evaluation of the resource persons during the workshop activity. The next workshop can be conducted with the theme of statistical inferential analysis in educational research. The statistical analysis is very helpful for educators to analyze research data in education.
\end{abstract}

\footnotetext{
Abstrak

Statistika menjadi menjadi bagian dari pelajaran matematika Wajib kelas XII serta matematika peminatan kelas XII. Pemahaman yang komprehensif tentang konsep dasar statistika sangat dibutuhkan untuk menyampaikan materi tersebut dikelas. Hasil diskusi dengan MGMP matematika kota kediri, diperlukan workshop untuk meningkatkan pemahaman guru matematika khususnya tentang materi distribusi normal, distribusi binomial. Selain itu juga disepakai materi tambahan yaitu item analisis dan standard setting dimana materi tersebut dapat implementasikan dalam melakukan evaluasi pembelajaran. Workshop dilakukan menjadi dua hari yaitu tanggal 4 November dengan materi distribusi normal. Pada akhir kegiatan tanggal ini, peserta diberi latihan soal yang harus diupload di google classroom. Tanggal 17 November 2020 adalah workshop kedua dengan materi distribusi binomial, item analysis, dan standard setting. Kegiatan workshop ini telah meningkatkan tingkat pemahaman peserta pada materi distribusi binomial dan distribusi normal. Peningkatan pemahaman diukur dari evaluasi dari jawaban latihan
} 
soal yang dikumpulkan oleh peserta dan evaluasi dari narasumber selama proses kegiatan workshop berlangsung. Workshop selanjutnya dapat dilakukan dengan tema tentang analisis statistika inferensia dalam penelitian pendidikan. Analisis statistika tersebut sangat membantu para pendidik untuk menganalisis data hasil penelitian dalam bidang pendidikan.

\section{PENDAHULUAN}

Pada kurikulum 2013 SMA, statistika menjadi menjadi bagian dari pelajaran matematika Wajib kelas XII serta matematika peminatan kelas XII. Ruang lingkup kompetensi dasar statistika pada SMA/SMK/MA mencakup ukuran pemusatan dan penyebaran data yang disajikan dalam bentuk tabel distribusi frekuensi dan histogram, menganalisis aturan pencacahan (aturan penjumlahan, aturan perkalian, permutasi, dan kombinasi) melalui masalah kontekstual, penentuan peluang kejadian majemuk (peluang kejadian-kejadian saling bebas, saling lepas, dan kejadian bersyarat) dari suatu percobaan acak, distribusi peluang binomial berkaitan dengan fungsi peluang binomial, karakteristik data berdistribusi normal yang berkaitan dengan data berdistribusi normal (Setiawan, 2019).

Statistika bermanfaat sebagai alat untuk melakukan analisis data di beberapa bidang. Di bidang sosial pemerintahan, Muhtarulloh et al., (2017) melakukan kegiatan pengabdian masyarakat berupa pelatihan dan pendampingan pengolahan data desa di lingkungan Kecamatan Bantarujeg Kabupaten Majalengka. Pada bidang kesehatan, analisis statistika juga sangat berperan dalam pengolahan dan analisis data. Fadmi (2020) melakukan pelatihan Analisis Data Bivariat menggunakan SPSS bagi dosen STIKES Mandala Waluya Kendari. Statistika juga bermanfaat untuk guru dalam melakukan Penelitian Tindakan Kelas. Analisis statistika digunakan sebagai alat analisis data yang didapatkan dari penelitian tindakan kelas tersebut. Suratmi et al. (2018) melakukan kegiatan pengabdian tentang analisis stastistika untuk pengolahan data hasil Penelitian Tindakan Kelas untuk MGMP Matematika SMP di Rayon Bandung Selatan. Kegiatan tersebut berhasil meningkatkan kemampuan analisis statistika secara signifikan.

Musyawarah Guru Mata Pelajaran (MGMP) adalah merupakan forum atau wadah dalam peningkatan profesionalisme guru. MGMP Matematika SMA Kota Kediri merupakan forum kerja guru matematika SMA di Kota Kediri. Kegiatan dimulai dengan diskusi dengan Ketua MGMP Matematika Kota Kediri. Beliau menjelaskan bahwa pemahaman guru matematika khususnya tentang materi statistika yang terkait dengan distribusi binomial, fungsi peluang binomial, karakteristik data berdistribusi normal yang berkaitan dengan data berdistribusi normal harus ditingkatkan. Kondisi ini dikarenakan banyak guru yang masih mengalami kendalam dalam memahami materi-materi tersebut. Berdasarkan informasi tersebut, maka kegiatan workshop akan mencakup materi tentang distribusi binomial, fungsi peluang binomial, karakteristik data berdistribusi normal.

Diskusi juga membahas bahwa metode pemaparan materi yang akan dilakukan. Hasilnya disepakati workshop akan dibagi menjadi dua hari yaitu 
tanggal 4 dan 17 November 2020. Dasar pertimbangan kegiatan kedua dilaksanakan agak lama dengan kegiatan workshop hari pertama adalah supaya peserta bisa fokus dalam mengerjakan soal yang akan diberikan. Hal ini dikarena peserta akan diberi soal yang akan dikerjakan setelah kegiatan workshop tanggal 4 November dan dikumpulkan secara online. Materi juga akan terdiri dari latihan soal yang diselesaikan secara manual dan secara komputerisasi menggunakan Microsoft excel.

Berdasarkan kendala tersebut, maka diselenggarakan kegiatan workshop implementasi statistika sebagai alat analisis dalam pengambilan keputusan di bidang pendidikan dengan komposisi materi meliputi konsep dasar statistika, distribusi binomial, dan distribusi normal. Pada kegiatan ini juga diberikan materi tentang analisis kualitas soal (Item Analysis) dan Standart Setting yang dapat digunakan oleh peserta dalam proses pembelajaran.

\section{METODE PELAKSANAAN}

Sasaran kegiatan adalah guru MGMP Matematika Kota Kediri. Workshop dilakukan menjadi dua hari yaitu tanggal 4 dan 17 November 2020. Secara garis besar, kegiatan ini terdiri 3 tahap yaitu Tahap 1 dimulai dengan penyampaian materi dan latihan soal pada tanggal 4 November 2020. Materi yang disampaikan pada tanggal 4 November 2020 terdiri dari materi konsep dasar statistika, peluang distribusi normal, dan konsep uji hipotesis. Selain penyampaian materi, juga terdapat latihan soal yang dibahas pada pertemuan tersebut. Pembahasan penyelesaiakan soal-soal dilakukan dengan dua cara yaitu dengan perhitungan secara manual dan menggunakan Microsoft excel.

Tahap kedua adalah membuat google classroom dan pemberian tugas yang akan dibahas pada pertemuan tanggal 17 November 2020. Setelah penyampaian materi tanggal 4 November selesai, para peserta diberi latihan soal yang harus dikerjakan. Soal dapat dikerjakan secara manual atau menggunakan Microsoft excel. Lembar jawaban peserta diupload di Google classroom yang telah dibuat oleh narasumber dengan kode kelas di google classroom adalah w7vduzn. Jawaban dari peserta dikoreksi oleh narasumber dan dibahas pada tanggal 17 November 2020.

Tahap ketiga dilakukan dengan penyampaian materi kedua tanggal 17 November 2020. Pada tanggal ini, kegiatan workshop terdiri dari dua yaitu pembahasan soal yang telah dikirim peserta di google classroom dan penyampaian materi dan latihan soal tentang Distribusi binomial, Classical Item analysis dan Standard Setting menggunakan metode Angoff.

\section{HASIL DAN PEMBAHASAN}

Kegiatan ini yang terbagi menjadi dua hari yaitu tanggal 4 November dan 17 November 2020 dilakukan secara offline dengan dengan menerapkan protokol kesehatan yang ketat. Kegiatan juga dapat berjalan dengan lancar sampai selesai. Peserta memiliki antusias yang tinggi dalam kegiatan ini terbukti dari banyaknya pertanyaan dan diskusi dengan narasumber. Peserta juga aktif mengirimkan jawaban dari soal yang diberikan di google classroom. 
Pada tanggal 4 November 2020, kegiatan dibuka oleh Ketua MGMP Matematika SMA Kota Kediri Bapak H. Sunyoto, S.Pd., M.Si. Setelah itu, dilakukan pemaparan materi pertama yang disampaikan Dr. Noer Hidayah, M.Si. Materi disampaikan menggunakan slide, dan diselingi dengan tanya jawab dengan peserta. Materi pertama meliputi konsep dasar statistika. Pada pemaparan materi konsep dasar statisika, narasumber menjelaskan konsep skala data, definisi analisis statistika deskriptif dan inferensia.

Narasumber menjelaskan terlebih dahulu memberikan pemahaman tentang definisi distribusi normal, bentuk kurva dari distribusi normal, dan pemakaian distribusi normal. Distribusi ini sangat penting dalam ilmu-ilmu sosial karena distribusi ini menjelaskan banyak karakterikstik manusia (Willard, 2020). Perhitungan nilai $z$ score dan perhitungan peluang dalam distribusi normal juga dijelaskan secara rinci. Peserta juga diberikan latihan soal dengan penyelesaian secara manual dan menggunakan Microsoft excel. Pada penyelesaian dengan microrosft excel, peserta dijelaskan tentang sintaks NORMDIST ( $x$, mean, standard_dev, cumulative ).

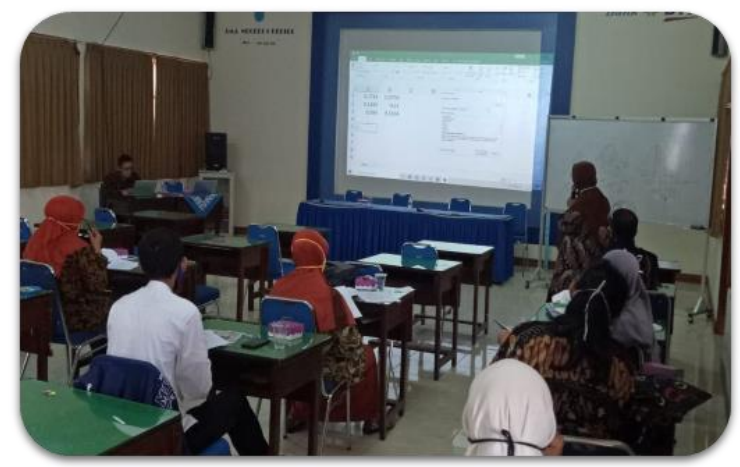

Gambar 1. Workshop pada tanggal 4 November 2020

Pada pukul 11.30 WIB, peserta diberi latihan soal dengan durasi waktu 30 menit untuk mengerjakan. Narasumber 1 dibantu dengan narasumber 2 berkeliling ke peserta untuk melihat jawaban dari peserta. Apabila peserta ada yang belum paham, narasumber akan langsung memberikan penjelasan terkait penyelesaian latihan soal tersebut. Di akhir sesi workshop tanggal 4 November, peserta diberikan latihan soal sebanyak 5 soal, dan hasilnya diupload di google classroom.

Workshop kedua tanggal 17 November tahun 2020 dimulai dengan pembahasan dari jawaban peserta yang telah diupload di google classroom. Pada sesi pembahasan soal ini dipandu oleh Jerhi Wahyu Fernanda, M.Si dan Dr. Noer Hidayah, M.Si. Hasil evaluasi terhadap jawaban peserta, dari 5 soal yang diberikan, peserta kesulitan pada soal yang kelima. Soal tersebut adalah sebagai berikut "Perusahaan elektronik sedang melakukan analisis untuk menentukan jangka waktu garansi yang akan diberikan perusahaan terhadap produk elektronik A. Garansi yang diberikan adalah penggantian komponen eletronik pada tersebut apabila mengalami kerusakan selama masa garansi. 
Berdasarkan data dari tim engineering perusahaan, didapatkan lifetime (waktu hidup) setiap komponen dalam produk elektronik tersebut sebesar 12.000 jam dengan standar deviasi 2.500. Berapakah jangka waktu garansi yang harus diberikan agar maksimal $10 \%$ dari produk $A$ perusahaan tersebut rusak selama masa garansi?".

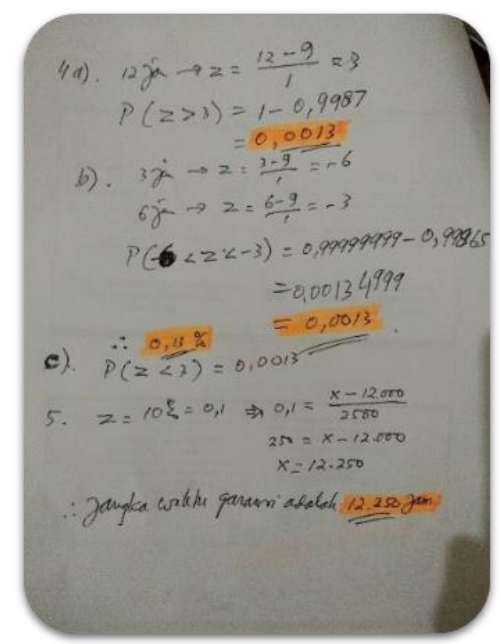

Gambar 2. Contoh hasil jawaan dari peserta yang diupload di google classroom

Kendala pada soal tersebut adalah peserta memahami bahwa maksimal $10 \%$ dari produk langsung dikonversi sebagai nilai Z. Padahal nilai ini adalah nilai probabilitas sebesar 0,1 . Nilai probabilitas 0,1 harus dikonversi menjadi nilai $z$ yaitu sebesar $-1,29$. Nilai ini dimasukkan ke dalam persamaan nilai standar $z$ yaitu $z=\frac{x-\mu}{\delta}$. Tahap selanjutnya nilai-nilai dalam soal dimasukkan ke persamaan menjadi $-1,29=\frac{x-12000}{2500}=8775 \mathrm{jam}$. Dari persamaan ini, proses selanjutnya adalah mecari nilai $x$.

Pemapanan materi pada pada tanggal 17 November 2020 disampaikan oleh Jerhi Wahyu Fernanda, M.Si. Materi distribusi binomial yang disampaikan terdiri dari formula dalam distribusi binomial, latihan kasus distribusi binomial, dan penerapan distribusi binomial pada uji hipotesis dua arah maupun satu arah.

Pada latihan soal pada kasus distribusi binomial peserta diberikan cara penyelesaian secara manual menggunakan tabel distribusi binomial dan secara komputerisasi dengan Microsoft Excel menggunakan sintaks BINOM.DIST(number_s;trials;probability_s;TRUE/FALSE).

Implementasi distribusi binomial dan distribusi normal juga dilakukan dalam beberapa penelitian. Diana (2017) menerapkan distribusi binomial dalam sebagai estimasi probabilitas kesuksesan uji coba kualitas layanan sistem informasi. Kesimpulan yang didapatkan dari penelitiannya adalah distribusi binomial dapat digunakan untuk mengestimasi kualitas layanan sistem 
informasi dengan memodelkan jumlah keberhasilan pada jumlah sampel $\mathrm{n}$ dari jumlah populasi $\mathrm{N}$.

Suparman (2015) menerapkan distribusi normal yaitu nilai $z$-score untuk menentukan nilai batas lulus (cut score). Penggunaan $z$-score dalam penentuan nilai batas lulus melibatkan sejumlah kegiatan penilaian, seperti nilai pekerjaan rumah (PR), nilai tugas, nilai ujian mid, kemudian semua komponen nilai tersbut dicari reratanya. Jadi dengan pendekatan berdasarkan $z$-score, nilai KKM ditentukan dengan rerata nilai kegiatan penilaian sebelumnya.

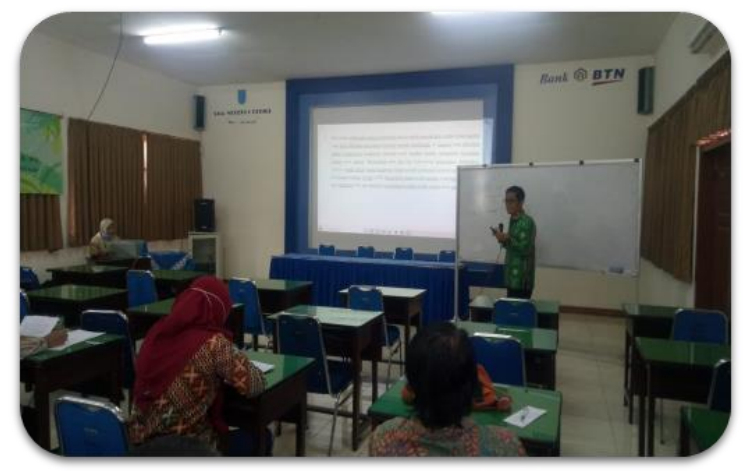

Gambar 3. Workshop pada tanggal 17 November 2020

Materi berikutnya adalah tentang analisis item. Analisis ini sangat bermanfaat dalam menentukan soal ujian yang digunakan sudah baik atau perlu diperbaiki (revisi). Analisis item (Item Analysis) merupakan metode statistika untuk menentukan kelayakan soal yang digunakan dalam suatu ujian (Price, 2017). Materi Analisis Item yang dijelaskan adalah metode teori test klasik (Classical Test Theory/CTT).

CTT merupakan metode dasar dalam penentuan kualitas soal yang sering digunakan dan metode ini merupakan dasar dalam banyak pengembangan teori pengukuran (Finch, W. H, French, 2019). Komponen dalam CTT terdiri dari dua yaitu tingkat kesukaran (Item difficulty) dan daya beda (item discrimination). Item difficulty adalah peluang peserta untuk menjawab soal dengan benar, dan dituangkan dalam bentuk proporsi. Item difficulty memiliki rentang nilai antara 0 sampai 1 dan dilambangkan dengan $p$. Item difficulty memiiki kategori dengan penjelasan sebagai berikut. Nilai $p \leq 0,3$ masuk dalam kategori sukar, $0,3<p \leq 0,70$ masuk kategori sedang, dan $p>$ 0,7 adalah soal dengan kategori mudah (Rao et al., 2016).

Item discriminant adalah kemampuan item (soal) untuk membedakan responden dalam hal ini adalah peserta ujian yang memiliki kemampuan baik dan kurang (Rust et al., 2021). Nilai ini dinotasikan dengan D. Item discriminat memiliki beberapa tingakatan kategori. $D \geq 0,4$ soal sangat baik, $D$ antara $0,3-$ 0,39 soal masuk dalam kategori baik (soal diterima tanpa tetapi perlu diperbaiki), antara $0,2-0,29$ soal cukup/diperbaiki, dan $D \leq 0,20$ soal dibuang/soal jelek (Rao et al., 2016). 
Soal ujian dinyatakan baik apabila memiliki nilai yang sesuai dengan kriteria Item difficulty dan Item discriminant. Penelitian lain juga menggunakan CTT untuk mengevaluasi soal ujian statistika. Hasilnya penelitiannya memberikan informasi bahwa, soal ujian statistika yang memenuhi kriteria Item Difficulty dan Item Discriminant sebanyak 21 soal (Fernanda, 2020). Erfan et al., (2020) menggunakan CTT dan Rasch Model untuk analisis kualitas soal kemampuan membedakan rangkaian seri dan parallel. Kesimpulan dari penelitiannya adalah 30 soal valid berdasarkan pendekatan CTT dari total 40 pertanyaan.

Herkusumo (2011) juga melakukan penelitian tentang Analisis Kualitas Instrumen Pengukuran Pemahaman Konsep Persamaan Kuadrat Melalui Teori Tes Klasik dan Rasch Model. Hasil analisis daya pembeda soal melalui pendekatan teori tes klasik menunjukkan bahwa soal nomor 1 dan 3 memiliki indeks daya beda yang sama yaitu sebesar 0,13 dengan kriteria buruk, soal nomor 2 dengan indeks daya beda sebesar 0,45 tergolong baik, dan soal nomor 4 masuk pada kriteria buruk dengan indeks daya beda sebesar 0,16. Berdasarkan hasil penelitian yang dilakukan oleh peneliti yang lain, didapatkan informasi bahwa metode analisis item salah satunya metode CTT sangat diperlukan dalam kegiatan evaluasi di bidang pendidikan.

Pada kegiatan ini, peserta melakukan simulasi perhitungan Item difficulty dan item discrimination berdasarkan data yang diberikan narasumber. Perhitungan dilakukan menggunakan microsot excel.

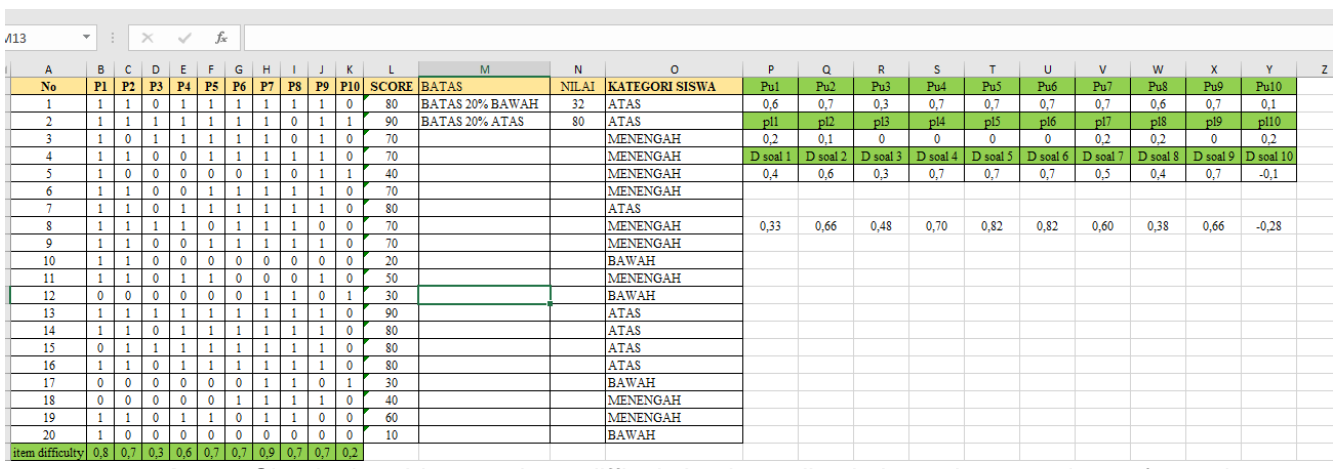

Gambar 4. Simulasi perhitungan item difficult dan item discriminant dengan microsoft excel

Materi terakhir membahas tentang Standar Setting. Sebelum disimulasikan prosedur dalam perhitungan Standar Setting, peserta dijelaskan definisi dan contoh penerapan metode tersebut. Standar Setting merupakan metode yang digunakan untuk penetapan standar atau skor kelulusan (Blömeke \& Gustafsson, 2017) Metode ini digunakan oleh Mardapi (2015) untuk penentuan kriteria ketuntasan minimal (KKM) peserta didik untuk mata pelajaran matematika SMP di Provinsi DI Yogyakarta. Penelitian tentang penerapan metode angoff dilakukan juga oleh Hairun (2015). Penelitiannya dilakukan untuk menentukan nilai batas lulus (passing score) mata pelajaran matematika siswa SMP Kota Ternate menggunakan metode Angoff. Hasil perhitungan menggunakan metode Angoff didapatkan nilai batas lulus sebesar 
67,5. Herkusumo (2011) juga menggunakan menggunakan metode Angoff dan metode Bookmark untuk penentuan batas skor kelulusan peserta didik untuk dapat lulus SMA/MA Program IPA dan IPS untuk mata pelajaran Bahasa Indonesia, Matematika IPS, Matematika IPA, Bahasa Inggris, Ekonomi, dan Fisika.

Materi Standard setting yang disampaikan adalah metode angoff. Dalam metode ini, guru disimulasikan untuk menjadi seorang juri (rater). Rater adalah seorang guru atau pendidik yang benar-benar menguasai kemampuan dari peserta didiknya. Langkah-langkah dalam metode Angoff sebagai berikut (1) Setiap panelis (rater) berperan sebagai peserta didik yang masuk pada kategori borderline (peserta yang masuk dalam kompetensi paling minimal). dan memberikan probabilitas menjawab dengan benar setiap item pertanyaan, (2) Mencari nilai rata-rata probabilitas yang benar dari keseluhan item pertanyaan dari semua rater (Cizek, 2012). Simulasi hasil jawaban dari para rater, dianalisis menggunakan Microsoft Excel untuk menentukan nilai cut skor kelulusan.

Hasil analisis terhadap kegiatan workshop ini, didapatkan informasi bahwa terdapat peningkatan pemahaman tentang materi distribusi binomial dan normal oleh para peserta. Informasi ini didapatkan dari evaluasi terhadap latihan soal yang telah diupload di google classroom, para peserta mampu menjawab $80 \%$ soal secara tepat. Pada saat workshop, juga diberikan soal yang harus langsung dikerjakan, dan para peserta $100 \%$ mampu menjawab soal-soal dengan tepat.

\section{KESIMPULAN}

Hasil workshop ini telah meningkatkan pemahaman tentang materi distribusi binomial dan normal oleh para peserta. Kesimpulan ini didasarkan pada jawaban peserta yang diupload di google classroom. Peserta mampu mejawab $80 \%$ soal secara tepat. Selain itu, pada saat workshop, juga diberikan soal yang harus langsung dikerjakan, dan para peserta $100 \%$ mampu menjawab soal-soal dengan tepat.

Pada kegiatan workshop selanjutnya, dapat dilakukan dengan tema tentang analisis statistika inferensia dalam penelitian di bidang pendidikan. Penentuan tema ini didasarkan masih belum kurangnya pemahaman tentang analisis statistika inferensia yang digunakan untuk menganalisis data penelitian dalam bidang pendidikan.

\section{UCAPAN TERIMA KASIH}

Terima kasih kepada MGMP Kota Kediri yang telah memberikan kesempatan untuk menjadi pemateri dalam workshop ini. Selain itu juga diucapkan banyak terima kasih pada Tim dari Prodi Tadris Matematika Institut Agama Islam Negeri (IAIN) Kediri yang telah membantu terlaksananya kegiatan workshop ini dengan lancar.

\section{DAFTAR RUJUKAN}

Blömeke, S., \& Gustafsson, J.-E. (2017). Standard setting in education. The nordic countries in an international perspective. In Methodology of 
Educational Measurement and Assessment.

Cizek, G. J. (2012). Setting Performance Standards Foundations, Methods, and Innovations. In Setting Performance Standards Foundations, Methods, and Innovations. https://doi.org/10.4324/9780203848203

Diana, D. (2017). Distribusi Binomial Sebagai Estimasi Probabilitas Kesuksesan Pada Uji Coba Kualitas Layanan Sistem Informasi. Jurnal IImiah Matrik, 19(3), 227-236. https://doi.org/https://doi.org/10.33557/jurnalmatrik.v19i3.390

Erfan, M., Maulyda, M. A., Hidayati, V. R., Astria, F. P., \& Ratu, T. (2020). Analisis Kualitas Soal Kemampuan Membedakan Rangkaian Seri dan Paralel Melalui Teori Tes Klasik dan Model Rasch. Indonesian Journal Of Educational Research and Review, 3(1), 11-19. https://doi.org/10.23887/ijerr.v3i1.24080

Fadmi, F. R., \& Buton, L. D. (2020). Pelatihan Analisis Data Bivariat Menggunakan SPSS Bagi Dosen STIKES Mandala Waluya Kendari. Jurnal Mandala Pengabdian Masyarakat, 1(1), 9-15. https://doi.org/10.35311/jmpm.v1i1.4

Fernanda, J. W., \& Hidayah, N. (2020). Classical Test Theory dan Rasch Model. SQUARE: Journal of Mathematics and Mathematics Education, 2(1), 49-60. https://doi.org/https://doi.org/10.21580/square.2020.2.1.5363

Finch, W. H, French, B. F. (2019). Educational and Psychological Measurement. Taylor \& Francis.

Herkusumo, A. P. (2011). Standard Setting Ujian Nasional Dengan Menggunakan Metode Angoff danBookmark. Jurnal Pendidikan Dan Kebudayaan, 17(3), 269. https://doi.org/10.24832/jpnk.v17i3.23

Mardapi, D., Hadi, S., \& Retnawati, H. (2015). Menentukan Kriteria Ketuntasan Minimal Berbasis Peserta Didik. Jurnal Penelitian Dan Evaluasi Pendidikan, 19(1), 38-45. https://doi.org/https://doi.org/https://doi.org/10.21831/pep.v15i2.1100

Nursahidin, Muhtarulloh, F., \& Nurdiana, E. (2017). Pengabdian Kepada Masyarakat Pelatihan dan Pendampingan Pengolahan Data Desa di Lingkungan Kecamatan Bantarujeg Kabupaten Majalengka. JURNAL ABDI: Media Pengabdian Kepada Masyarakat, 3(1), 6-10. https://doi.org/http://dx.doi.org/10.26740/ja.v3n1.p6-10

Price, L. R. (2017). Psychometric Methods. Theory into Practice. The Guilford Press.

Rao, C., Kishan Prasad, H., Sajitha, K., Permi, H., \& Shetty, J. (2016). Item analysis of multiple choice questions: Assessing an assessment tool in medical students. International Journal of Educational and Psychological Researches, 2(4), 201. https://doi.org/10.4103/23952296.189670

Rust, J., Konsiski, M., \& Stillwell. (2021). Modern Psychometrics The Science of Psychological Assessment (Fourth edi). Routledge.

Setiawan, E. P. (2019). Analisis muatan literasi statistika dalam buku teks matematika Kurikulum 2013. Pythagoras: Jurnal Pendidikan Matematika, 14(2), 163-177. https://doi.org/10.21831/pg.v14i2.28558 
Suparman. (2015). Menentukan Cut Score pada Evaluasi Pendidikan. ALMANAR Jurnal Komunikasi Dan Pendidikan Islam, 4(1), 1-24. https://doi.org/doi.org/10.36668/jal.v4i2.59

Suratmi, S., Purwaningsih, S. S., Sartika, E., \& Suryani, A. (2018). Statistika untuk Pengolahan Data Hasil Penelitian Tindakan Kelas (PTK) Kelompok Musyawarah Guru Mata Pelajaran (MGMP) di SMP Rayon Bandung Selatan. Jurnal Difusi. Jurnal Hasil Penelitian \& Pengabdian Masyarakat Politeknik Negeri Bandung, 1(1), 53. https://doi.org/https://doi.org/10.35313/difusi.v1i1.1016

Willard, C. A. (2020). An Introduction to Basic Statistical Concept and Analysis (Second edi). Taylor \& Francis.

Yahya Hairun. (2015). Mathematics cut of score with standar setting Angoff method. Delta-Pi:Jurnal Matematika Dan Pendidikan Matematika, 4(1), 1-12. https://doi.org/http://dx.doi.org/10.33387/dpi.v4i1.140 